\title{
Dietary Protein for Training Adaptation and Body Composition Manipulation in Track and Field Athletes
}

\author{
Oliver C. Witard \\ University of Stirling \\ Ina Garthe \\ Norwegian Olympic and Paralympic Committee and Confederation of Sport \\ Stuart M. Phillips \\ McMaster University
}

\begin{abstract}
Track and field athletes engage in vigorous training that places stress on physiological systems requiring nutritional support for optimal recovery. Of paramount importance when optimizing recovery nutrition are rehydration and refueling which are covered in other papers in this volume. Here, we highlight the benefits for dietary protein intake over and above requirements set out in various countries at $\sim 0.8-1.0 \mathrm{~g} \cdot \mathrm{kg}$ body mass $(\mathrm{BM})^{-1} \cdot \mathrm{day}^{-1}$ for training adaptation, manipulating body composition, and optimizing performance in track and field athletes. To facilitate the remodeling of protein-containing structures, which are turning over rapidly due to their training volumes, track and field athletes with the goal of weight maintenance or weight gain should aim for protein intakes of $\sim 1.6 \mathrm{~g} \cdot \mathrm{kg} \mathrm{BM}^{-1} \cdot \mathrm{day}^{-1}$. Protein intakes at this level would not necessarily require an overemphasis on protein-containing foods and, beyond convenience, does not suggest a need to use protein or amino acid-based supplements. This review also highlights that optimal protein intakes may exceed $1.6 \mathrm{~g} \cdot \mathrm{kg} \mathrm{BM}^{-1} \cdot \mathrm{day}^{-1}$ for athletes who are restricting energy intake and attempting to minimize loss of lean BM. We discuss the underpinning rationale for weight loss in track and field athletes, explaining changes in metabolic pathways that occur in response to energy restriction when manipulating protein intake and training. Finally, this review offers practical advice on protein intakes that warrant consideration in allowing an optimal adaptive response for track and field athletes seeking to train effectively and to lose fat mass while energy restricted with minimal (or no) loss of lean BM.
\end{abstract}

Keywords: high-quality weight loss, protein recommendations, protein turnover

Dietary protein is widely regarded as a key nutrient for allowing optimal training adaptation (Tipton, 2008) and optimizing body composition (Hector \& Phillips, 2018; Murphy et al., 2015) in athletes including track and field athletes. Track and field athletics encompasses a broad spectrum of events including race walking; running (sprints, middle- and long-distance events, and hurdling); throwing (shot put, javelin, discus, and hammer); and jumping (long jump, triple jump, high jump, and pole vault), all with different ideals for the optimum performance physique (Hirsch et al., 2016). Most track and field athletes are familiar with the concept of high-quality weight loss (Sundgot-Borgen \& Garthe,

(C) 2019 The Authors. Published by Human Kinetics, Inc. This is an Open Access article distributed under the terms of the Creative Commons Attribution License CC BY 4.0, which permits unrestricted noncommercial and commercial use, distribution, and reproduction in any medium, provided the original work is properly cited, the new use includes a link to the license, and any changes are indicated. See https:// creativecommons.org/licenses/by/4.0/. This license does not cover any third-party material that may appear with permission in the article.

Witard is with Physiology, Exercise and Nutrition Research Group, Faculty of Health Sciences and Sport, University of Stirling, Stirling, Scotland. Garthe is with Norwegian Olympic and Paralympic Committee and Confederation of Sport, Oslo, Norway. Phillips is with McMaster University, Hamilton, Ontario, Canada. Address author correspondence to Oliver C. Witard at oliver.witard@stir.ac.uk.
2011), which describes the loss of fat mass while preserving, or even increasing, fat-free mass (i.e., muscle tissue) during a voluntary period of energy restriction. Many athletes engage in weight loss programs to "make weight" for competition (i.e., combat sports) or for aesthetic reasons (i.e., gymnasts and divers). However, the "Holy Grail" for most, if not all, track and field athletes during weight loss is to optimize their ratio of strength, power, or endurance to body weight for a performance advantage.

Since the previous International Association of Athletics Federations consensus statement (O'Connor et al., 2007), the evidence underpinning nutrition strategies for adaptation and physique manipulation in athletes has evolved considerably. In particular, recent attention has focused on advancing understanding of the role of protein nutrition in allowing "optimal" training adaptation (Tipton, 2008) and body composition (Hector \& Phillips, 2018; Pasiakos et al., 2015). Accordingly, here we update the latest evidence-based protein recommendations for training adaptation and promoting, if desired, high-quality weight loss in athletes, with specific application to track and field athletes. In Figure 1, we provide a theoretical framework for understanding recommended dietary protein intakes for optimal adaptation, as opposed to offsetting deficiency and meeting minimal needs for protein in athletes. The scientific evidence that underpins this framework is critically evaluated. To provide practical context, the next sections of 


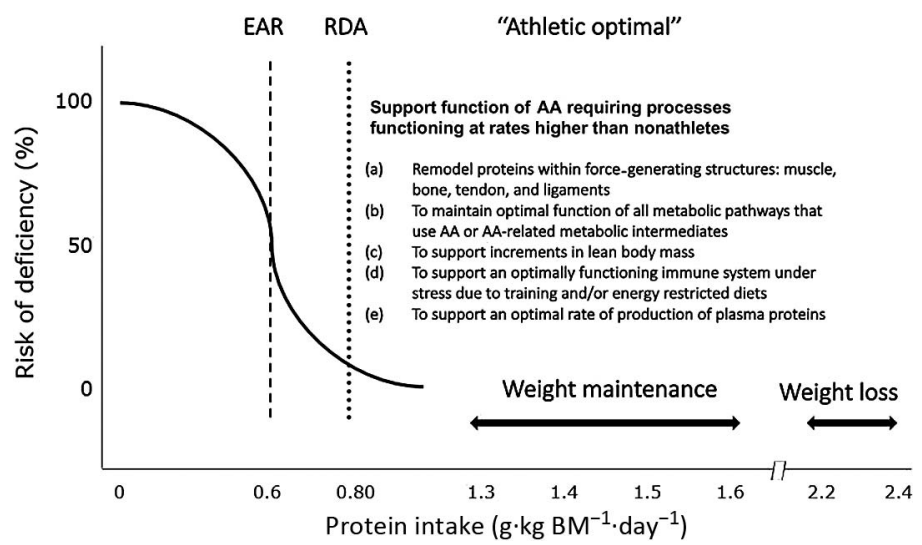

Figure 1 - Theoretical framework for understanding recommended dietary protein intakes for optimal adaptation in track and field athletes. $\mathrm{AA}=$ amino acid; $\mathrm{EAR}=$ estimated average requirement; $\mathrm{RDA}=$ recommended daily allowance; $\mathrm{BM}=$ body mass.

this review outline the principles of weight loss and expand on why weight loss is an important goal for many track and field athletes across sprint, throwing, jumping, and race walking disciplines.

\section{Weight Loss Principles for Athletes}

The principles of weight loss and weight gain are similar because both require continuous energy imbalance between energy intake and/or energy expenditure. Most, but not all, athletes strive for high-quality weight loss, which can be defined as the loss of fat mass while preserving, or even increasing, fat-free mass (i.e., muscle tissue) during a voluntary period of energy restriction. Notable exceptions to this rule include shot put and discus throwers in which fat mass as well as muscle mass are considered functional for performance. In general, the already high energy expenditure associated with structured exercise training in high-performance athletes means that restricting energy intake is likely the necessary, and perhaps the preferred (Dhurandhar et al., 2015) option, to achieve weight loss in this population. Since weight loss is a result of a predominance of catabolism in adipose tissue, and the gain of muscle mass (i.e., lean body mass [LBM]) is a result of predominance of anabolism in skeletal muscle, this requires the track and field athlete to practice a meticulously tailored meal plan, combined with an adequate and sports-specific strength training stimulus for muscle growth. Suffice to say, while it would be easier to gain muscle in an energy surfeit and to lose fat while in an energy deficit, there are several publications about trained individuals in which the process has been shown to occur (Garthe et al., 2011a; Haakonssen et al., 2013; Longland et al., 2016).

\section{Why Weight Management Is of Importance for Track and Field Athletes}

Both gradual and rapid weight loss practices are commonly employed across athletic populations. Rapid weight loss (i.e., $3-10 \%$ of body weight over $\sim 96 \mathrm{hr}$ ) is based predominantly on the loss of bodily fluids caused by passive or active dehydration and is most typically used by weight-class athletes prior to weigh-in (e.g., combat sports). Track and field athletes in jumping or long-distance events, where body weight is closely related to performance, may also use rapid weight loss as a strategy to take advantage of a lighter body weight during competition. Moreover, long-distance runners and race walkers may be well hydrated at the start of the race but modestly dehydrated at the finish, due to voluntary dehydration during the race (Coyle, 2004). Although the prevalence of rapid weight loss strategies among track and field athletes are unknown, the risk of serious health and performance impairments caused by even moderate dehydration are well documented (Shirreffs et al., 2004), making the relationship between rapid weight loss and performance a complex concept (Coyle, 2004). Track and field athletes involved in jumping and throwing events may be an exception to this rule.

A more gradual weight loss with the goal to maximize the ratio of strength, power, or endurance to body weight is typical for track and field athletes when performance depends on efficient horizontal (e.g., long-distance running) or vertical (e.g., high jump) movements. In these events, excessive "nonuseful" body weight as fat mass can be a disadvantage for performance. A gradual weight loss of $0.5-1 \mathrm{~kg} /$ week due to a modest increase in energy expenditure and/or, more likely, a lowered energy intake will primarily comprise of fat mass. This weight loss requires an energy deficit of $\sim 500-1,000 \mathrm{kcal} / \mathrm{day}$, respectively, but understanding that stochastic formulas for weight loss of these rates will vary considerably on an interindividual basis. However, due to metabolic adaptations that occur at the onset of weight loss combined with a gradually lowered body weight, the energy deficit required for weight loss is less during the initial stages of dieting than after 2-3 weeks (Dhurandhar et al., 2015).

While weight loss during the first weeks of negative energy balance is largely attributed to changes in glycogen, protein, and fluids, long-term weight loss is mainly attributed to changes in fat mass and to a varying degree loss of LBM (Weinheimer et al., 2010). As a result, the degree of the energy deficit needs to be individualized. Long periods of energy deficit are inherently stressful from both physiological and psychological perspectives and increase the risk of impaired immune function, injuries, hormonal disturbances, sleep disturbances, loss of bone mass (particularly if calcium and vitamin D intake are inadequate), and other processes detrimental to health and performance caused by relative energy deficiency (Mountjoy et al., 2014). Thus, considering the counterproductive responses related to long-term energy deficiency and the link between body weight and performance in some track and field events, ongoing monitoring and evaluation during weight loss by professionals is warranted (Mountjoy et al., 2018). In practice, most track and field athletes reduce the volume of resistance training during a weight-loss period prior to competition in favor of more event-specific training. This removal of resistance exercise as a primary external stimulus for muscle maintenance combined with negative energy balance is likely to exacerbate the loss of LBM. However, as discussed below, studies have shown that it is possible, even for the elite athlete, to maintain LBM during a weight loss intervention (Garthe et al., 2011b; Mettler et al., 2010). The main factors that determine highquality weight loss appear to be an adequate dietary intake of highquality protein distributed evenly and frequently in relation to exercise and recovery, combined with additional strength training as stimuli for lean tissue growth.

At the other end of the spectrum, certain athletes, such as those in power-oriented throwing events, will strive to gain weight by maximizing LBM, as their performance depends on high absolute muscle strength and power. Athletes with the goal to gain body 
weight could be at risk of excessive intake of food and supplements and may benefit from professional support. The potential for muscle growth depends not only on nutrition, but also on an athlete's genetics and resistance training history. A positive energy balance alone has been shown to elicit an important anabolic effect (Bray et al., 2012), but combining strength training and a positive energy balance results in the most effective gain in LBM (Kreider et al., 1996; Tipton \& Wolfe, 2004).

Although there are few studies on weight gain in athletes, it has been suggested that an increase in LBM of $0.25-0.5 \mathrm{~kg} /$ week may be a realistic goal for the strength/power-based athlete (Rozenek et al., 2002) at least over a relatively short-term (12-16 weeks) period, but this rate would slow drastically with time. To achieve this gain in LBM, an energy surplus of $\sim 500 \mathrm{kcal} /$ day is recommended for the track and field athlete. However, athletes with a long history of heavy strength training may have less potential to gain LBM (Garthe et al., 2011b). Therefore, the excess energy intake in a weight gain intervention should be carefully considered and monitored as greater rates of weight gain are likely to include increments in body fat in trained athletes

\section{Dietary Protein for Training Adaptation in Track and Field Athletes}

Protein is important for optimizing the physical and likely metabolic adaptations that occur in skeletal muscle, as well as other tissues, in response to exercise (Tipton, 2008), both during states of energy balance and energy restriction (Figure 1). The physiological basis for phenotypic changes that take place with either resistanceor endurance-based exercise training stems from changes in the quantity, type, and/or activity of various muscle proteins (Hawley et al., 2006). The turnover, or remodeling, of all proteins is a constant and concurrent process. Hence, at any given time, misfolded, older damaged (posttranslational damage) proteins are degraded through muscle protein breakdown (MPB) and are replaced with new functional muscle proteins through muscle protein synthesis (MPS). Muscle protein is gained if rates of MPS exceed MPB, termed positive net muscle protein balance. Conversely, muscle protein is lost if MPB exceeds MPS in a state of negative net muscle protein balance, as may be the case during periods of weight loss.

Although an optimum muscle mass may not necessarily equal maximal muscle mass (Tipton et al., 2007), a prerequisite for success in predominantly strength/power-based track (e.g., sprinters) and field (e.g., long jumpers, shot put, javelin, and discus throwers) athletes is to achieve an optimal power to body weight ratio. Muscle hypertrophy stems from the remodeling of the contractile myofibrillar proteins in response to resistance exercise training. More applicable to the endurance-based track and field athlete such as middle- and long-distance runners, nonhypertrophic muscle adaptation also results from muscle protein remodeling that stems primarily from a protein turnover favoring a positive net protein balance of sarcoplasmic and mitochondrial muscle proteins. Although both MPS and MPB processes are modulated by protein ingestion and exercise, MPS is 4-5 times more responsive than MPB (Biolo et al., 1997) and changes in MPB are of far lesser concern. As a result, best practice nutrition guidelines for muscle adaptation in athletes are primarily based on protein recommendations for stimulation of MPS. It should also be noted that dietary and/or nutritional factors that purport to suppress MPB (i.e., branched-chain amino acids; Borgenvik et al., 2012) are not likely to aid training adaptation. The main reason for this statement is the recognition that the replacement of damaged or nonfunctional proteins and the muscle remodeling process is advantageous (Stokes et al., 2018; Tipton et al., 2018).

As a broad guideline, a daily protein intake between 1.3 and $1.7 \mathrm{~g} \cdot \mathrm{kg} \mathrm{BM}{ }^{-1} \cdot \mathrm{day}^{-1}$ is recommended for athletes (Morton \& Phillips, 2018; Rodriguez et al., 2009). What appears clear, based on the most recent evidence-based review and meta-analysis, is that intakes of protein greater than $1.6 \mathrm{~g} \cdot \mathrm{kg} \mathrm{BM}^{-1} \cdot \mathrm{day}^{-1}$ and possibly as high as $2.2 \mathrm{~g} \cdot \mathrm{kg} \mathrm{BM}^{-1} \cdot \mathrm{day}^{-1}$ do not further enhance gains in LBM in weight-stable trained individuals (Morton et al., 2018). Moreover, due to the satiating effect of protein compared with other macronutrients (Veldhorst et al., 2008), it is plausible that excessive protein intakes could displace intakes of other important nutrients including carbohydrate and be detrimental to training adaptation (MacKenzie-Shalders et al., 2015). Protein recommendations are now thought to be better expressed on a meal-by-meal, or serving-by-serving basis, rather than daily basis (Murphy et al., 2016; Witard et al., 2016). This approach stems from accumulating evidence that multiple factors, including the per meal/serving dose, protein type (i.e., source); meal pattern; and timing (in relation to training, sleep, and other nutrients) of ingested protein, as well as the co-ingestion of other nutrients, all modulate the response of MPS to ingested protein (Witard et al., 2016). In brief, based on these studies the dose of protein for track and field athletes to consume on a per serving/meal basis for maximal stimulation of MPS would equate to $\sim 0.3-0.4 \mathrm{~g} / \mathrm{kg}$ BM (Moore et al., 2015). Consumed over 3-4 feeding occasions, this equates to a daily protein intake in the region of $1.3-1.7 \mathrm{~g} \cdot \mathrm{kg} \mathrm{BM}^{-1} \cdot \mathrm{day}^{-1}$. While the $0.3 \mathrm{~g} / \mathrm{kg} \mathrm{BM}$ target serving represents a safe intake for protein, this guideline was based on studies that administered isolated intact proteins, such as whey protein (Moore et al., 2015), gave rise only to acute measures of MPS (i.e., meal-to-meal), and included no other macronutrients and as such would themselves be considered optimal only under the specific conditions employed in the studies. We and others (Gorissen \& Witard, 2018; van Vliet et al., 2015) contend that the optimal per meal "real world" serving of a proteinrich food for maximal stimulation of MPS may be closer to 0.4-0.5 g/kg BM when we consider real foods, not isolated proteins, and the coingestion of other macronutrients that would alter rates of digestion and thus patterns of aminoacidemia to stimulate MPS. Hence, for an $80-\mathrm{kg}$ male sprinter, male long jumper, or female javelin thrower, this guideline represents an $\sim 30$ g protein serving size, with an example meal plan displayed in Table 1. In contrast, but employing the similar rationale, a 55-kg female long-distance runner or race walker would consume $\sim 20 \mathrm{~g}$ protein serving, with an example meal plan displayed in Table 2.

In terms of protein type, leucine-rich rapidly digested protein sources, such as whey protein, have been shown to elicit a greater stimulation of MPS during training recovery compared with slowly digested proteins of lower leucine composition, such as soy, micellar casein (high in leucine and more slowly digested), and wheat (Gorissen et al., 2016; Tang et al., 2009). There also is evidence that track and field athletes would benefit from distributing their daily protein intake evenly (e.g., 4-5 equally spaced servings) throughout the day (Mamerow et al., 2014). This strategy might include a slow-releasing, protein-rich, snack at bedtime (Trommelen \& van Loon, 2016). Importantly, in the context of this review, these protein recommendations are based on scientific data generated in weight-stable (i.e., in energy balance) trained, but by no means elite, athletic individuals. 
Table 1 Example Meal Plan for an 80-kg Male Sprinter, Male Long Jumper, or Female Javelin Thrower

\begin{tabular}{lll}
\hline Time & Meal & Foods providing $\sim \mathbf{3 0} \mathbf{g}$ of protein in highlighted meals during the day \\
\hline 08.00 & Breakfast & 250-g oatmeal porridge and 200-ml low-fat milk \\
$09.30-11.00$ & Strength training & Water and/or sports drink/bar/gel \\
11.00 & Recovery meal & 300 -g Greek yogurt with granola \\
12.30 & Lunch & Omelet of two eggs and cheese, toast/salad \\
16.00 & Dinner & 120-g chicken with rice and vegetables \\
$17.00-19.30$ & Event-specific training & Water and/or sports drink/bar/gel \\
19.30 & Recovery meal & 300 -g cottage cheese with apple and berries \\
22.00 & Evening meal & $100-\mathrm{g}$ tuna in a mixed pasta salad \\
\hline
\end{tabular}

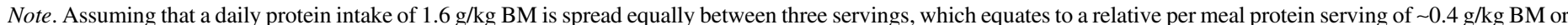
$\sim 30 \mathrm{~g}$ of protein expressed on an absolute basis. Carbohydrate-rich foods should be added to meet the individual daily energy needs. BM = body mass.

Table 2 Example Meal Plan for a 55-kg Female Long-Distance Runner or Race Walker

\begin{tabular}{lll}
\hline Time & Meal & Foods providing $\sim \mathbf{2 0} \mathbf{g}$ of protein in highlighted meals during the day \\
\hline 08.00 & Breakfast & 200-g Greek yogurt and granola \\
$09.30-11.00$ & Strength training & Water and/or sports drink/bar/gel \\
11.00 & Recovery meal & 500-ml smoothie (yogurt and berries) \\
12.30 & Lunch & Two fried eggs and toast/salad \\
16.00 & Dinner & 100-g salmon with potatoes and vegetables \\
$17.00-19.30$ & Event-specific training & Water and/or sports drink/bar/gel \\
19.30 & Recovery meal & 500-ml smoothie with yogurt, fruit, and berries \\
22.00 & Evening meal & Ham and cheese sandwich and 200-ml low-fat milk \\
\hline
\end{tabular}

Note. Assuming that a daily protein intake of $1.6 \mathrm{~g} \cdot \mathrm{kg} \mathrm{BM}^{-1} \cdot \mathrm{day}^{-1}$ is spread equally between three highlighted servings, which equates to a relative per meal protein serving of $\sim 0.4 \mathrm{~g} / \mathrm{kg} \mathrm{BM}$ or $\sim 20 \mathrm{~g}$ of protein expressed on an absolute basis. Carbohydrate-rich foods should be added to meet the individual daily energy needs. BM = body mass.

\section{Dietary Protein for High-Quality Weight Loss in Track and Field Athletes}

Dietary protein is widely regarded as a key nutrient for manipulating body composition during weight loss in both nonathletic and athletic populations. The benefits of increasing dietary protein levels above the recommended daily allowance of $0.8 \mathrm{~g} \cdot \mathrm{kg} \mathrm{BM}^{-1} \cdot \mathrm{day}^{-1}$ on body composition during weight loss has been extensively investigated in overweight and obese populations (Josse et al., 2011; Krieger et al., 2006; Longland et al., 2016; Wycherley et al., 2012). In contrast, the evidence base that currently informs daily protein recommendations for athletes during weight loss is limited to only a handful of studies. To date, the most comprehensive review of protein recommendations during weight loss in athletes was conducted by Helms et al. (2014). This systematic review of six published studies concluded that a daily protein intake of 1.8 $2.7 \mathrm{~g} \cdot \mathrm{kg} \mathrm{BM}{ }^{-1} \cdot \mathrm{day}^{-1}$ or $2.3-3.1 \mathrm{~g} \cdot \mathrm{kg} \mathrm{LBM}^{-1}$. $\mathrm{day}^{-1}$ was estimated as optimal to preserve LBM and still results in the reduction of fat mass during energy restriction in lean, resistance-trained athletes (Helms et al., 2014). Noteworthy, however, the fact is that only two (Mettler et al., 2010; Walberg et al., 1988) of the six studies included in this review (Helms et al., 2014) actually compared matched groups of athletes consuming different levels of protein intake or quantified training. Hence, the practical application of this systematic review to the track and field athlete is perhaps best interpreted on a study-by-study basis.

Of the articles included in this systematic review (Helms et al., 2014), perhaps the study most relevant to strength/power-based track and field athletes was published by Mettler et al. (2010). This tightly controlled study measured changes in BM, fat mass, and LBM following a 2-week period of energy restriction in resistancetrained men who consumed $\sim 60 \%$ of their habitual energy intake, while maintaining their normal training schedule ( $4-5$ sessions per week, including $\geq 2$ resistance training sessions). The control group of athletes continued with their habitual daily protein intake $(1.0 \mathrm{~g} / \mathrm{kg}$ $\mathrm{BM}$ or $1.2 \mathrm{~g} / \mathrm{kg} \mathrm{LBM}$ ) during 2 weeks of energy restriction, whereas the experimental group increased their protein intake to $2.3 \mathrm{~g} / \mathrm{kg} \mathrm{BM}$, equivalent to $\sim 2.7 \mathrm{~g} / \mathrm{kg} \mathrm{LBM}$ or $35 \%$ of individual total energy intake. Energy intake was matched between dietary conditions. Interestingly, whereas the control group of athletes lost $1.6 \mathrm{~kg}$ of LBM over the 2 weeks of energy restriction, there was a negligible $(0.3 \mathrm{~kg})$ decline in LBM in the high protein-consuming group. Given that both groups lost $\sim 1.3 \mathrm{~kg}$ of fat mass, in aggregate, the decline in total $\mathrm{BM}$ was greater in the control $(3 \mathrm{~kg})$ versus high $(1.5 \mathrm{~kg})$ protein group. These findings were remarkably similar, both qualitatively and quantitatively, to an earlier study in male body builders (Walberg et al., 1988). Also consistent with this observation, a recent case study in an elite female endurance athlete demonstrated an increase in LBM when protein intake was increased to $2.6 \mathrm{~g} \cdot \mathrm{kg} \mathrm{BM}^{-1} \cdot \mathrm{day}^{-1}$ during $\sim 2$ weeks of reduced energy availability (Haakonssen et al., 2013). Taken together, in terms of practical implications, these data suggest that strength/power or endurance-based track and field athletes with the goal of preserving or increasing LBM during weight loss should consume a dietary protein intake in excess of $1.6 \mathrm{~g} \cdot \mathrm{kg} \mathrm{BM}^{-1} \cdot \mathrm{day}^{-1}$ (Figure 1). Moving forward, as is the case for weight-stable athletes, protein recommendations for high-quality weight loss should move toward expressing recommendations on a meal-to-meal rather than daily basis. 
A series of elaborate laboratory-based metabolic studies provide a mechanistic link between dietary protein intake, exercise training, skeletal muscle protein turnover, and the regulation of muscle mass during energy restriction. The general consensus is that the main driver of LBM loss during weight loss is a reduced stimulation of MPS, with minimal changes in MPB observed during energy restriction (Hector et al., 2018). This phenomenon is intuitive given that MPS is an energetically expensive process, requiring $\sim 4$ moles of adenosine triphosphate to add each amino acid during the elongation process of MPS (Browne \& Proud, 2002). As such, the attenuated rate of MPS during energy restriction suggests an adaptive mechanism to conserve energy during weight loss. Accordingly, studies have demonstrated an $\sim 25 \%$ decrease in fasting rates of MPS during the early (5-10 days) stages of an energy restricted diet (Areta et al., 2014; Hector et al., 2018; Pasiakos et al., 2010).

The findings from several mechanistic studies also indicate that the careful planning of dietary protein intake in combination with resistance exercise training provides an effective strategy for track and field athletes to counter the impaired response of MPS during weight loss (Hector \& Phillips, 2018; Pasiakos et al., 2015). Two recent studies demonstrated that reduced fasting rates of MPS following energy restriction were offset for the next $48 \mathrm{hr}$ when young men performed resistance-based exercise (Areta et al., 2014; Hector et al., 2018). Moreover, whereas 21 days of moderate energy restriction (equivalent to a $20 \%$ energy deficit) with a daily protein intake of $0.8 \mathrm{~g} \cdot \mathrm{kg} \mathrm{BM}{ }^{-1} \cdot \mathrm{day}^{-1}$ resulted in a suppressed postprandial response of MPS to a $20 \mathrm{~g}$ serving of milk, increasing daily protein intake to twice $\left(1.6 \mathrm{~g} \cdot \mathrm{kg} \mathrm{BM}^{-1} \cdot \mathrm{day}^{-1}\right)$ or thrice $\left(2.4 \mathrm{~g} \cdot \mathrm{kg} \mathrm{BM}^{-1} \cdot \mathrm{day}^{-1}\right)$ the recommended daily allowance restored postprandial rates of MPS in response to the same 20-g milk serving to levels observed during energy balance (Pasiakos et al., 2013). Moreover, a recent study reported a protein dose-dependent increase in the postexercise response of MPS during energy restriction in trained young men (Areta et al., 2014). The highest MPS response was observed with ingestion of $30 \mathrm{~g}$ of protein; however, the increase in MPS was linear from 15 to $30 \mathrm{~g}$ with no dose fed above that intake. Thus, it remains unknown whether the response of MPS is further increased with a protein dose greater than $30 \mathrm{~g}$ during energy restriction. Nonetheless, taken together these data highlight the interaction of increased daily protein intake and resistance training in stimulating MPS response during weight loss.

Few studies have examined the impact of protein type (Hector et al., 2015) or the meal pattern (e.g., daily protein intake distributed equally between meals or skewed toward the evening meal; Murphy et al., 2018) of protein intake on rates of MPS during energy restriction, particularly within an athletic context. Nevertheless, if we assume the recommended protein intake during energy restriction in track and field athletes ranges from 1.6 to $2.4 \mathrm{~g} \cdot \mathrm{kg} \mathrm{BM}^{-1} \cdot \mathrm{day}^{-1}$ (Figure 1), the following calculations can be made to inform refined protein recommendations on a meal-tomeal or serving-to-serving basis. For the same $80-\mathrm{kg}$ male sprinters, male long jumpers, or female javelin throwers who spread a daily protein intake of $1.6 \mathrm{~g} \cdot \mathrm{kg} \mathrm{BM}{ }^{-1} \cdot \mathrm{day}^{-1}$ equally between four or five servings (i.e., three meals and one or two snacks, including a bedtime snack), this equates to a relative per meal protein serving of $\sim 0.4 \mathrm{~g} / \mathrm{kg}$ BM or $\sim 32 \mathrm{~g}$ of protein expressed on an absolute basis for three meals and the remainder of his protein as snacks. Alternately, if we assume a daily protein recommendation at the high end of this recommended range (i.e., $2.4 \mathrm{~g} \cdot \mathrm{kg} \mathrm{BM}^{-1} \cdot \mathrm{day}^{-1}$ ), this equates to a per meal protein serving of $\sim 0.5 \mathrm{~g} / \mathrm{kg} \mathrm{BM}$ or a 40 -g protein dose. To this end, these calculations provide only an informed estimate regarding the recommended dose of protein that athletes should consider consuming on a meal-to-meal basis during energy restriction. However, we contend there is reasonable scientific evidence for us to propose, with reasonable confidence, that this target per meal protein dose exceeds the $0.3-0.4 \mathrm{~g} / \mathrm{kg}$ BM recommendation set for athletes during energy balance (Tables 1 and 2).

Despite convincing evidence that protein intakes to preserve LBM are increased in athletes during weight loss, optimizing protein recommendations for high-quality weight loss in elite track and field athletes also likely depends on several case-specific factors. In theory, three general factors determine the level of LBM loss during energy restriction and should be considered when prescribing protein recommendations for the athlete. First, a severe energy deficit that requires a fast rate of weight loss is associated with a more pronounced loss of LBM compared with a slower rate of weight loss (Garthe et al., 2011). Second, individuals who inherently possess greater muscle mass are more susceptible to losing LBM during weight loss compared with those athletes who possess less (Heymsfield et al., 2011). Third, the habitual protein intake of the athlete prior to energy restriction should be considered when setting the target level of protein intake for the track and field athlete during weight loss. In theory, the athlete who habitually consumes a high protein diet, possesses a significant volume of muscle mass, has a high intrinsic metabolic capacity to degrade amino acids and generate urea, and selects a more aggressive weight loss strategy should target a daily protein intake toward the higher $\left(2.4 \mathrm{~g} \cdot \mathrm{kg} \mathrm{BM}^{-1} \cdot \mathrm{day}^{-1}\right)$ end of the recommended range (Helms et al., 2014). Finally, it is likely that the practice of resistance training is a potent local (i.e., muscle specific) stimulus to allow the exercised muscle to retain lean mass during weight loss. This point is illustrated by data from Longland et al. (2016) who showed that athletes consuming a protein intake of only $1.2 \mathrm{~g} \cdot \mathrm{kg} \mathrm{BM}^{-1} \cdot \mathrm{day}^{-1}$ were able to completely ablate their loss of lean mass, whereas those consuming a protein intake of $2.4 \mathrm{~g} \cdot \mathrm{kg} \mathrm{BM}{ }^{-1} \cdot \mathrm{day}^{-1}$ actually gained a modest but significant amount of LBM. We propose that in fact of the two stimuli, the practice of resistance exercise is going to be far more potent than increasing protein intake as a stimulus for promoting retention of LBM.

\section{High Protein Diets for Health and Performance in Track and Field Athletes}

There are a number of long-standing claims that a high protein diet, as advocated here for track and field athletes during weight loss, is detrimental for athlete health (Lowery \& Devia, 2009; Martin et al., 2005; Metges \& Barth, 2000). However, at present, there is no scientific evidence to substantiate the claims that protein will enhance risk of adverse renal health, particularly within athletic populations (Phillips, 2017; Phillips et al., 2016; Van Elswyk et al., 2018). Moreover, as opposed to what is often touted as a negative effect of high protein in stimulating adverse outcomes for bone, a recent meta-analysis from the U.S. National Osteoporosis Foundation concluded that protein is actually a bone supportive nutrient (Shams-White et al., 2017) particularly when athletes are consuming adequate calcium and vitamin D. In short, track and field athletes who consume a high protein diet during weight loss are not placing themselves at increased risk of kidney problems or poor bone health.

Perhaps the greater concern for the track and field athlete who embarks on a high-protein weight-loss diet relates to the choice of 
macronutrient to replace with an increased protein intake. By default, dietary carbohydrate and/or fat intake must be adjusted to accommodate for the increase in protein content of the diet. According to a meta-analysis, increasing the protein content of an energy restricted diet at the expense of carbohydrate, rather than fat, results in a greater decline in BM and fat mass during weight loss (Krieger et al., 2006). However, this meta-analysis was based on studies conducted in overweight and obese populations. In the context of athlete performance, concern has been raised regarding the impact of reducing carbohydrate availability on maintaining training quality and subsequent performance during periods of weight loss. To address this concern, Mettler et al. (2010) standardized carbohydrate intake at habitual levels $\left(3.4 \mathrm{~g} \cdot \mathrm{kg} \mathrm{BM}^{-1} \cdot \mathrm{day}^{-1}\right)$ and increased protein intake at the expense of fat intake during 2 weeks of energy restriction in resistance-trained men. In addition to improving body composition, athletes who consumed the highprotein/low-fat diet either maintained or improved their performance on a series of strength-based exercises.

A separate, but related consideration for the track and field athlete in terms of performance during energy restriction concerns the rate of weight loss. A slower rate of weight loss $(0.7 \%$ body weight loss per week) in elite athletes resulted in more favorable performance and body composition outcomes than when athletes embarked on a more rapid weight loss $(1.4 \%$ body weight loss per week) program (Garthe et al., 2011a). As a general guideline, track and field athletes are recommended to engage in a slower rate $(\sim 0.5 \mathrm{~kg} /$ week $)$ of weight loss and make subtle adjustments to both their carbohydrate and fat intakes ( $\sim 20 \%$ of total energy intake) rather than excessively reducing either macronutrient alone when increasing the protein content of an energy restricted diet. In theory, this measured approach will address fears over reducing dietary carbohydrate or fat intakes to levels that may adversely affect the health and performance of the track and field athlete.

\section{Amino Acid-Based Supplements for High-Quality Weight Loss in Track and Field Athletes}

Anecdotally, there is significant interest in the role of protein-based supplements during weight loss for improved body composition and performance in athletic populations, including track and field athletes. In this regard, most interest has focused on dietary supplementation with the branched-chain amino acids (BCAA), leucine, isoleucine, and valine. There is ample evidence that ingested BCAA (Karlsson et al., 2004; Moberg et al., 2016), in particular leucine (Kimball \& Jefferson, 2006), result in stimulation of the molecular signaling pathways that switch on MPS. Recent work also demonstrated that ingestion of $5.6 \mathrm{~g}$ of BCAA alone immediately following a bout of resistance exercise resulted in a moderate $(\sim 27 \%)$ increased stimulation of MPS during recovery compared with a carbohydrate placebo (Jackman et al., 2017); however, this effect was almost certainly due to the presence of leucine as the other two BCAA have no effect in activating cell signaling and stimulating MPS synthesis (Atherton et al., 2010). Similar results also were demonstrated with the ingestion of leucine or the leucine metabolite $\beta$-hydroxy- $\beta$ methylbutyrate alone (Wilkinson et al., 2013). However, interestingly the magnitude of this increased stimulation of MPS during exercise recovery with BCAA ingestion was $\sim 50 \%$ inferior to the MPS response to ingesting a 20-g dose of whey protein containing similar amounts of BCAA (Witard et al., 2014). The current knowledge base that directly investigates the impact of proteinbased supplements, including BCAA, on body composition during energy restriction is limited and thus future work in the context of weight loss is warranted.

\section{General Conclusions}

Tables 3 and 4 provide an overview of the "knowns" and "unknowns" regarding protein recommendations for training adaptation and body composition manipulation in track and field athletes. In summary, optimal levels of protein intake in athletes clearly exceed the current protein recommended daily allowance of between 0.8 and $1.0 \mathrm{~g} \cdot \mathrm{kg} \mathrm{BM}^{-1} \cdot \mathrm{day}^{-1}$. As outlined, dietary protein intakes in the range of $1.3-1.7 \mathrm{~g} \cdot \mathrm{kg} \mathrm{BM}^{-1} \cdot \mathrm{day}^{-1}$ are optimal for athletes who are maintaining their body weight. In contrast, athletes wishing to undertake high-quality weight loss are advised to engage in resistance exercise and consume dietary protein intakes in quantities above $1.6 \mathrm{~g} \cdot \mathrm{kg} \mathrm{BM}^{-1} \cdot \mathrm{day}^{-1}$ and closer to $2.4 \mathrm{~g} \cdot \mathrm{kg}$ $\mathrm{BM}^{-1} \cdot \mathrm{day}^{-1}$ to promote the retention and potentially increase LBM. Leucine is a key and critical amino acid for stimulating the cell signaling pathways that control MPS and should be emphasized in protein sources consumed postexercise to trigger a rise in MPS during weight loss. There are benefits to consuming

\section{Table 3 Protein Recommendations for Training Adaptation and Body Composition Manipulation in Track and Field Athletes}

\section{What we know from scientific literature and how this knowledge may be translated into everyday practice for track and field} athletes

(a) The optimum daily protein intake for the weight stable track and field athletes exceeds the protein $\mathrm{RDA}\left(0.8-1.0 \mathrm{~g} \cdot \mathrm{kg} \mathrm{BM}^{-1} \cdot \mathrm{day}^{-1}\right)$ set for the general adult population.

(b) The optimum daily protein intake for track and field athletes with the goal of weight maintenance or weight gain ranges from 1.3 to $1.7 \mathrm{~g} \cdot \mathrm{kg}$ $\mathrm{BM}^{-1} \cdot$ day $^{-1}$ (refer to Table 1$)$.

(c) The optimum per meal/serving of protein for track and field athletes with the goal of weight maintenance or weight gain ranges from 0.3 to $0.4 \mathrm{~g} / \mathrm{kg}$ BM per meal (refer to Table 1).

(d) Very high protein intakes of $>2.5 \mathrm{~g} \cdot \mathrm{kg} \mathrm{BM}^{-1} \cdot$ day $^{-1}$ offer no adaptive advantage.

(e) The optimum daily protein intake for track and field athletes with the goal of high-quality weight loss exceeds $1.6 \mathrm{~g} \cdot \mathrm{kg} \mathrm{BM}^{-1} \cdot \mathrm{day}^{-1}$ and may be as high as $2.4 \mathrm{~g} \cdot \mathrm{kg} \mathrm{BM}^{-1} \cdot \mathrm{day}^{-1}$.

(f) Track and field athletes who consume a high protein diet (e.g., $2.4 \mathrm{~g} \cdot \mathrm{kg} \mathrm{BM}^{-1} \cdot$ day $^{-1}$ ) during weight loss are not at increased risk of kidney problems or poor bone health.

Note. RDA = recommended daily allowance; BM = body mass. High-quality weight loss is defined as the loss of fat mass while preserving, or even increasing, lean body mass. 


\section{Table 4 Future Research Directions in Dietary Protein for Training Adaptation and Body Composition Manipulation in Track and Field Athletes}

What research has yet to discover

(a) The optimum per meal/serving of commonly consumed protein-rich Studies designed to characterize the dose-response of MPS to ingested foods for maximal stimulation of MPS during exercise recovery.

(b) The longer term benefits of higher protein intakes on high quality weight loss in track and field athletes. soy protein.

Individual or small group case studies in elite athletes with a more realistic level of weight loss (e.g., $20 \%$ vs. $40 \%$ energy deficit) over a longer period of training (>2 weeks).

(c) The optimum per meal/serving of protein during weight loss in track Studies designed to characterize the dose-response of MPS to ingested and field athletes. protein during energy restriction in athletes.

(d) The impact of protein source and timing on body composition during Studies should determine rates of MPS after manipulating the daytime pattern weight loss in track and field athletes.

(e) Individual variability in body composition responses to dietary protein manipulation during weight loss in track and field athletes. composition responses during energy restriction.

(f) Event-specific protein needs in track and field athletics related to body Individual or small group case studies across all track and field events. composition manipulation.

Note. MPS $=$ muscle protein synthesis.

food-based protein sources due to their nutrient density (Phillips et al., 2015), which would be beneficial for track and field athletes especially those who are on energy-restricted diets.

\section{Acknowledgments}

The manuscript preparation and editing was undertaken by O. C. Witard, I. Garthe, and S. M. Phillips. All authors approved the final version of the paper. We also would like to thank all volunteers who participated in research projects, providing valuable data and information. O. C. Witard reports having received honoraria from PepsiCo. S. M. Phillips reports having received funding, honoraria, and travel expenses from the U.S. National Dairy Council, funding from PepsiCo, and funding from the Dairy Farmers of Canada.

\section{References}

Areta, J.L., Burke, L.M., Camera, D.M., West, D.W., Crawshay, S., Moore, D.R., ... Coffey, V.G. (2014). Reduced resting skeletal muscle protein synthesis is rescued by resistance exercise and protein ingestion following short-term energy deficit. American Journal of Physiology-Endocrinology and Metabolism, 306(8), E989-E997. PubMed ID: 24595305 doi:10.1152/ajpendo.00590.2013

Atherton, P.J., Smith, K., Etheridge, T., Rankin, D., \& Rennie, M.J. (2010). Distinct anabolic signalling responses to amino acids in C2C12 skeletal muscle cells. Amino Acids, 38(5), 1533-1539. PubMed ID: 19882215 doi:10.1007/s00726-009-0377-x

Biolo, G., Tipton, K.D., Klein, S., \& Wolfe, R.R. (1997). An abundant supply of amino acids enhances the metabolic effect of exercise on muscle protein. American Journal of Physiology-Endocrinology and Metabolism, 273(1), E122-E129. PubMed ID: 9252488 doi:10.1152/ajpendo.1997.273.1.E122

Borgenvik, M., Apro, W., \& Blomstrand, E. (2012). Intake of branchedchain amino acids influences the levels of MAFbx mRNA and MuRF-1 total protein in resting and exercising human muscle. American Journal of Physiology-Endocrinology and Metabolism, 302(5), E510-E521. PubMed ID: 22127230 doi:10.1152/ajpendo. 00353.2011
Bray, G.A., Smith, S.R., de Jonge, L., Xie, H., Rood, J., Martin, C.K., . . Redman, L.M. (2012). Effect of dietary protein content on weight gain, energy expenditure, and body composition during overeating: A randomized controlled trial. JAMA, 307(1), 47-55. PubMed ID: 22215165 doi:10.1001/jama.2011.1918

Browne, G.J., \& Proud, C.G. (2002). Regulation of peptide-chain elongation in mammalian cells. European Journal of Biochemistry, 269(22), 5360-5368. PubMed ID: 12423334 doi:10.1046/j.1432-1033.2002. 03290.x

Coyle, E.F. (2004). Fluid and fuel intake during exercise. Journal of Sports Sciences, 22(1), 39-55. PubMed ID: 14971432 doi:10.1080/ 0264041031000140545

Dhurandhar, E.J., Kaiser, K.A., Dawson, J.A., Alcorn, A.S., Keating, K.D., \& Allison, D.B. (2015). Predicting adult weight change in the real world: A systematic review and meta-analysis accounting for compensatory changes in energy intake or expenditure. International Journal of Obesity, 39(8), 1181-1187. doi:10.1038/ijo. 2014.184

Garthe, I., Raastad, T., Refsnes, P.E., Koivisto, A., \& Sundgot-Borgen, J. (2011a). Effect of two different weight-loss rates on body composition and strength and power-related performance in elite athletes. International Journal of Sport Nutrition and Exercise Metabolism, 21(2), 97-104. PubMed ID: 21558571 doi:10.1123/ijsnem.21.2.97

Garthe, I., Raastad, T., \& Sundgot-Borgen, J. (2011b). Long-term effect of weight loss on body composition and performance in elite athletes. International Journal of Sport Nutrition and Exercise Metabolism, 21(5), 426-435. PubMed ID: 21896944 doi:10.1123/ijsnem.21.5.426

Gorissen, S.H., Horstman, A.M., Franssen, R., Crombag, J.J., Langer, H., Bierau, J., ... van Loon, L.J. (2016). Ingestion of wheat protein increases in vivo muscle protein synthesis rates in healthy older men in a randomized trial. The Journal of Nutrition, 146(9), 1651-1659. PubMed ID: 27440260 doi:10.3945/jn.116.231340

Gorissen, S.H.M., \& Witard, O.C. (2018). Characterising the muscle anabolic potential of dairy, meat and plant-based protein sources in older adults. Proceedings of the Nutrition Society, 77(1), 20-31. PubMed ID: 28847314 doi:10.1017/S002966511700194X

Haakonssen, E.C., Martin, D.T., Burke, L.M., \& Jenkins, D.G. (2013). Increased lean mass with reduced fat mass in an elite female cyclist returning to competition: Case study. International Journal of Sports 
Physiology and Performance, 8(6), 699-701. PubMed ID: 23538431 doi:10.1123/ijspp.8.6.699

Hawley, J.A., Tipton, K.D., \& Millard-Stafford, M.L. (2006). Promoting training adaptations through nutritional interventions. Journal of Sports Sciences, 24(7), 709-721. doi:10.1080/02640410500482727

Hector, A.J., Marcotte, G.R., Churchward-Venne, T.A., Murphy, C.H., Breen, L., von Allmen, M., ... Phillips, S.M. (2015). Whey protein supplementation preserves postprandial myofibrillar protein synthesis during short-term energy restriction in overweight and obese adults. The Journal of Nutrition, 145(2), 246-252. PubMed ID: 25644344 doi:10.3945/jn.114.200832

Hector, A.J., McGlory, C., Damas, F., Mazara, N., Baker, S.K., \& Phillips, S.M. (2018). Pronounced energy restriction with elevated protein intake results in no change in proteolysis and reductions in skeletal muscle protein synthesis that are mitigated by resistance exercise. FASEB Journal, 32(1), 265-275. doi:10.1096/fj.201700158RR

Hector, A.J., \& Phillips, S.M. (2018). Protein recommendations for weight loss in elite athletes: A focus on body composition and performance. International Journal of Sport Nutrition and Exercise Metabolism, 28(2), 170-177. PubMed ID: 29182451 doi:10.1123/ijsnem.2017-0273

Helms, E.R., Zinn, C., Rowlands, D.S., \& Brown, S.R. (2014). A systematic review of dietary protein during caloric restriction in resistance trained lean athletes: A case for higher intakes. International Journal of Sport Nutrition and Exercise Metabolism, 24(2), 127-138. PubMed ID: 24092765 doi:10.1123/ijsnem.2013-0054

Heymsfield, S.B., Thomas, D., Nguyen, A.M., Peng, J.Z., Martin, C., Shen, W., .. Muller, M.J. (2011). Voluntary weight loss: Systematic review of early phase body composition changes. Obesity Reviews, 12(5), e348-e361. doi:10.1111/j.1467-789X.2010.00767.x

Hirsch, K.R., Smith-Ryan, A.E., Trexler, E.T., \& Roelofs, E.J. (2016). Body composition and muscle characteristics of division I track and field athletes. Journal of Strength and Conditioning Research, 30(5), 12311238. PubMed ID: 27100166 doi:10.1519/JSC.0000000000001203

Jackman, S.R., Witard, O.C., Philp, A., Wallis, G.A., Baar, K., \& Tipton, K.D. (2017). Branched-chain amino acid ingestion stimulates muscle myofibrillar protein synthesis following resistance exercise in humans. Frontiers in Physiology, 8, 390. PubMed ID: 28638350 doi:10. 3389/fphys.2017.00390

Josse, A.R., Atkinson, S.A., Tarnopolsky, M.A., \& Phillips, S.M. (2011). Increased consumption of dairy foods and protein during diet- and exercise-induced weight loss promotes fat mass loss and lean mass gain in overweight and obese premenopausal women. The Journal of Nutrition, 141(9), 1626-1634. doi:10.3945/jn.111.141028

Karlsson, H.K., Nilsson, P.A., Nilsson, J., Chibalin, A.V., Zierath, J.R., \& Blomstrand, E. (2004). Branched-chain amino acids increase p70S6k phosphorylation in human skeletal muscle after resistance exercise. American Journal of Physiology-Endocrinology and Metabolism, 287(1), E1-E7. doi:10.1152/ajpendo.00430.2003

Kimball, S.R., \& Jefferson, L.S. (2006). Signaling pathways and molecular mechanisms through which branched-chain amino acids mediate translational control of protein synthesis. The Journal of Nutrition, 136(1), 227S-231S. doi:10.1093/jn/136.1.227S

Krieger, J.W., Sitren, H.S., Daniels, M.J., \& Langkamp-Henken, B. (2006). Effects of variation in protein and carbohydrate intake on body mass and composition during energy restriction: A metaregression. The American Journal of Clinical Nutrition, 83(2), 260-274. PubMed ID: 16469983 doi:10.1093/ajcn/83.2.260

Kreider, R.B., Klesges, R., Harmon, K., Grindstaff, P., Ramsey, L., Bullen, D., ... Almada, A. (1996). Effects of ingesting supplements designed to promote lean tissue accretion on body composition during resistance training. International Journal of Sport Nutrition and Exercise Metabolism, 6(3), 234-246.
Longland, T.M., Oikawa, S.Y., Mitchell, C.J., Devries, M.C., \& Phillips, S.M. (2016). Higher compared with lower dietary protein during an energy deficit combined with intense exercise promotes greater lean mass gain and fat mass loss: A randomized trial. The American Journal of Clinical Nutrition, 103(3), 738-746. PubMed ID: 26817506 doi:10.3945/ajen.115.119339

Lowery, L.M., \& Devia, L. (2009). Dietary protein safety and resistance exercise: What do we really know? Journal of the International Society of Sports Nutrition, 6, 3. PubMed ID: 19138405 doi:10.1186/ 1550-2783-6-3

MacKenzie-Shalders, K.L., Byrne, N.M., Slater, G.J., \& King, N.A. (2015). The effect of a whey protein supplement dose on satiety and food intake in resistance training athletes. Appetite, 92, 178-184. PubMed ID: 25979566 doi:10.1016/j.appet.2015.05.007

Mamerow, M.M., Mettler, J.A., English, K.L., Casperson, S.L., ArentsonLantz, E., Sheffield-Moore, M., ... Paddon-Jones, D. (2014). Dietary protein distribution positively influences $24-\mathrm{h}$ muscle protein synthesis in healthy adults. The Journal of Nutrition, 144(6), 876880. doi:10.3945/jn.113.185280

Martin, W.F., Armstrong, L.E., \& Rodriguez, N.R. (2005). Dietary protein intake and renal function. Nutrition \& Metabolism, 2, 25. PubMed ID: 16174292 doi:10.1186/1743-7075-2-25

Metges, C.C., \& Barth, C.A. (2000). Metabolic consequences of a high dietary-protein intake in adulthood: Assessment of the available evidence. The Journal of Nutrition, 130(4), 886-889. PubMed ID: 10736347 doi:10.1093/jn/130.4.886

Mettler, S., Mitchell, N., \& Tipton, K.D. (2010). Increased protein intake reduces lean body mass loss during weight loss in athletes. Medicine \& Science in Sports \& Exercise, 42(2), 326-337. doi:10.1249/MSS. 0b013e3181b2ef8e

Moberg, M., Apro, W., Ekblom, B., van Hall, G., Holmberg, H.C., \& Blomstrand, E. (2016). Activation of mTORC1 by leucine is potentiated by branched-chain amino acids and even more so by essential amino acids following resistance exercise. American Journal of Physiology-Cell Physiology, 310(11), C874-C884. PubMed ID: 27053525 doi:10.1152/ajpcell.00374.2015

Moore, D.R., Churchward-Venne, T.A., Witard, O., Breen, L., Burd, N.A., Tipton, K.D., \& Phillips, S.M. (2015). Protein ingestion to stimulate myofibrillar protein synthesis requires greater relative protein intakes in healthy older versus younger men. The Journals of Gerontology, Series A: Biological Sciences \& Medical Sciences, 70(1), 57-62. doi:10.1093/gerona/glu103

Morton, R.W., Murphy, K.T., McKellar, S.R., Schoenfeld, B.J., Henselmans, M., Helms, E., ... Phillips, S.M. (2018). A systematic review, meta-analysis and meta-regression of the effect of protein supplementation on resistance training-induced gains in muscle mass and strength in healthy adults. British Journal of Sports Medicine, 52(6), 376-384. PubMed ID: 28698222

Morton, R.W., \& Phillips, S.M. (2018). Does protein supplementation really augment hypertrophy in older persons with resistance exercise training? The American Journal of Clinical Nutrition, 107(6), 10541056. PubMed ID: 29771273 doi:10.1093/ajcn/nqy068

Mountjoy, M., Sundgot-Borgen, J., Burke, L., Carter, S., Constantini, N., Lebrun, C., ... Ljungqvist, A. (2014). The IOC consensus statement: Beyond the female athlete triad-Relative energy deficiency in sport (RED-S). British Journal of Sports Medicine, 48(7), 491-497. PubMed ID: 24620037 doi:10.1136/bjsports-2014-093502

Mountjoy, M., Sundgot-Borgen, J.K., Burke, L.M., Ackerman, K.E., Blauwet, C., Constantini, N., . . Budgett, R. (2018). IOC consensus statement on relative energy deficiency in sport (RED-S): 2018 update. British Journal of Sports Medicine, 52(11), 687-697. PubMed ID: 29773536 doi:10.1136/bjsports-2018-099193 
Murphy, C.H., Hector, A.J., \& Phillips, S.M. (2015). Considerations for protein intake in managing weight loss in athletes. European Journal of Sport Science, 15(1), 21-28. PubMed ID: 25014731 doi:10.1080/ 17461391.2014.936325

Murphy, C.H., Oikawa, S.Y., \& Phillips, S.M. (2016). Dietary protein to maintain muscle mass in aging: A case for per-meal protein recommendations. The Journal of Frailty \& Aging, 5(1), 49-58. PubMed ID: 26980369

Murphy, C.H., Shankaran, M., Churchward-Venne, T.A., Mitchell, C.J., Kolar, N.M., Burke, L.M., ... Phillips, S.M. (2018). Effect of resistance training and protein intake pattern on myofibrillar protein synthesis and proteome kinetics in older men in energy restriction. The Journal of Physiology, 596(11), 2091-2120. PubMed ID: 29532476 doi:10.1113/JP275246

O'Connor, H., Olds, T., Maughan, R.J., and International Association of Athletics Federations. (2007). Physique and performance for track and field events. Journal of Sports Sciences, 25(Suppl. 1), S49-S60. doi:10.1080/02640410701607296

Pasiakos, S.M., Cao, J.J., Margolis, L.M., Sauter, E.R., Whigham, L.D., McClung, J.P., . . . Young, A.J. (2013). Effects of high-protein diets on fat-free mass and muscle protein synthesis following weight loss: A randomized controlled trial. FASEB Journal, 27(9), 3837-3847. doi:10.1096/fj.13-230227

Pasiakos, S.M., Margolis, L.M., \& Orr, J.S. (2015). Optimized dietary strategies to protect skeletal muscle mass during periods of unavoidable energy deficit. FASEB Journal, 29(4), 1136-1142. doi:10.1096/ fj. 14-266890

Pasiakos, S.M., Vislocky, L.M., Carbone, J.W., Altieri, N., Konopelski, K., Freake, H.C., . . Rodriguez, N.R. (2010). Acute energy deprivation affects skeletal muscle protein synthesis and associated intracellular signaling proteins in physically active adults. The Journal of Nutrition, 140(4), 745-751. PubMed ID: 20164371 doi:10.3945/jn. 109.118372

Phillips, S.M. (2017). Current concepts and unresolved questions in dietary protein requirements and supplements in adults. Frontiers in Nutrition, 4, 13. PubMed ID: 28534027 doi:10.3389/fnut.2017.00013

Phillips, S.M., Chevalier, S., \& Leidy, H.J. (2016). Protein "requirements" beyond the RDA: Implications for optimizing health. Applied Physiology, Nutrition, and Metabolism, 41(5), 565-572. PubMed ID: 26960445 doi:10.1139/apnm-2015-0550

Phillips, S.M., Fulgoni, V.L. III, Heaney, R.P., Nicklas, T.A., Slavin, J.L., \& Weaver, C.M. (2015). Commonly consumed protein foods contribute to nutrient intake, diet quality, and nutrient adequacy. The American Journal of Clinical Nutrition, 101(6), 1346S-1352S. doi:10.3945/ajcn.114.084079

Rodriguez, N.R., Di Marco, N.M., \& Langley, S. (2009). American College of Sports Medicine position stand. Nutrition and athletic performance. Medicine \& Science in Sports \& Exercise, 41(3), 709731. doi:10.1249/MSS.0b013e31890eb86

Rozenek, R., Ward, P., Long, S., \& Garhammer, J. (2002). Effects of highcalorie supplements on body composition and muscular strength following resistance training. The Journal of Sports Medicine and Physical Fitness, 42(3), 340-347. PubMed ID: 12094125

Shams-White, M.M., Chung, M., Du, M., Fu, Z., Insogna, K.L., Karlsen, M.C., ... Weaver, C.M. (2017). Dietary protein and bone health: A systematic review and meta-analysis from the National Osteoporosis Foundation. The American Journal of Clinical Nutrition, 105(6), 1528-1543. PubMed ID: 28404575

Shirreffs, S.M., Merson, S.J., Fraser, S.M., \& Archer, D.T. (2004). The effects of fluid restriction on hydration status and subjective feelings in man. The British Journal of Nutrition, 91(6), 951-958. PubMed ID: 15182398 doi:10.1079/BJN20041149

Stokes, T., Hector, A.J., Morton, R.W., McGlory, C., \& Phillips, S.M. (2018). Recent perspectives regarding the role of dietary protein for the promotion of muscle hypertrophy with resistance exercise training. Nutrients, 10(2), E180. PubMed ID: 29414855 doi:10.3390/ nu10020180

Sundgot-Borgen, J., \& Garthe, I. (2011). Elite athletes in aesthetic and Olympic weight-class sports and the challenge of body weight and body compositions. Journal of Sports Sciences, 29(Suppl. 1), S101S114. doi:10.1080/02640414.2011.565783

Tang, J.E., Moore, D.R., Kujbida, G.W., Tarnopolsky, M.A., \& Phillips, S.M. (2009). Ingestion of whey hydrolysate, casein, or soy protein isolate: Effects on mixed muscle protein synthesis at rest and following resistance exercise in young men. Journal of Applied Physiology, 107(3), 987-992. doi:10.1152/japplphysiol.00076.2009

Tipton, K.D. (2008). Protein for adaptations to exercise training. European Journal of Sport Science, 8(2), 107-118. doi:10.1080/ 17461390801919102

Tipton, K.D., Hamilton, D.L., \& Gallagher, I.J. (2018). Assessing the role of muscle protein breakdown in response to nutrition and exercise in humans. Sports Medicine, 48(Suppl. 1), 53-64. doi:10.1007/s40279017-0845-5

Tipton, K.D., Jeukendrup, A.E., \& Hespel, P. (2007). Nutrition for the sprinter. Journal of Sports Sciences, 25(Suppl. 1), S5-S15. doi:10. 1080/02640410701607205

Trommelen, J., \& van Loon, L.J. (2016). Pre-sleep protein ingestion to improve the skeletal muscle adaptive response to exercise training. Nutrients, 8(12), 763. PubMed ID: 27916799 doi:10.3390/ nu8120763.

Van Elswyk, M.E., Weatherford, C.A., \& McNeill, S.H. (2018). A systematic review of renal health in healthy individuals associated with protein intake above the US recommended daily allowance in randomized controlled trials and observational studies. Advances in Nutrition, 9(4), 404-418. doi:10.1093/advances/nmy026

Tipton, K.D., \& Wolfe, R.R. (2004). Protein and amino acids for athletes. Journal of Sports Sciences, 22(1), 65-79.

van Vliet, S., Burd, N.A., \& van Loon, L.J.C. (2015). The skeletal muscle anabolic response to plant- versus animal-based protein consumption. The Journal of Nutrition, 145(9), 1981-1991. PubMed ID: 26224750 doi:10.3945/jn.114.204305

Veldhorst, M., Smeets, A., Soenen, S., Hochstenbach-Waelen, A., Hursel, R., Diepvens, K., ... Westerterp-Plantenga, M. (2008). Proteininduced satiety: Effects and mechanisms of different proteins. Physiology \& Behavior, 94(2), 300-307. doi:10.1016/j.physbeh.2008.01.003

Walberg, J.L., Leidy, M.K., Sturgill, D.J., Hinkle, D.E., Ritchey, S.J., \& Sebolt, D.R. (1988). Macronutrient content of a hypoenergy diet affects nitrogen retention and muscle function in weight lifters. International Journal of Sports Medicine, 9(4), 261-266. doi:10. 1055/s-2007-1025018

Weinheimer, E.M., Sands, L.P., \& Campbell, W.W. (2010). A systematic review of the separate and combined effects of energy restriction and exercise on fat-free mass in middle-aged and older adults: Implications for sarcopenic obesity. Nutrition Reviews, 68(7), 375-388. doi:10.1111/j.1753-4887.2010.00298.x

Wilkinson, D.J., Hossain, T., Hill, D.S., Phillips, B.E., Crossland, H., Williams, J., ... Atherton, P.J. (2013). Effects of leucine and its metabolite beta-hydroxy-beta-methylbutyrate on human skeletal muscle protein metabolism. The Journal of Physiology, 591(11), 29112923. PubMed ID: 23551944 doi:10.1113/jphysiol.2013.253203 
Witard, O.C., Jackman, S.R., Breen, L., Smith, K., Selby, A., \& Tipton, K.D. (2014). Myofibrillar muscle protein synthesis rates subsequent to a meal in response to increasing doses of whey protein at rest and after resistance exercise. The American Journal of Clinical Nutrition, 99(1), 86-95. PubMed ID: 24257722 doi:10.3945/ajcn.112.055517

Witard, O.C., Wardle, S.L., Macnaughton, L.S., Hodgson, A.B., \& Tipton, K.D. (2016). Protein considerations for optimising skeletal muscle mass in healthy young and older adults. Nutrients, 8(4), 181. PubMed ID: 27023595 doi:10.3390/nu8040181

Wycherley, T.P., Moran, L.J., Clifton, P.M., Noakes, M., \& Brinkworth, G.D. (2012). Effects of energy-restricted high-protein, low-fat compared with standard-protein, low-fat diets: A meta-analysis of randomized controlled trials. The American Journal of Clinical Nutrition, 96(6), 1281-1298. PubMed ID: 23097268 doi:10.3945/ajcn.112.044321 